\title{
MANUFACTURING OF SUN TRACKING AND REFLECTOR SYSTEM TO SUITABLE PV PANEL UNDER EGYPTIAN CONDITIONS
}

A. M. Okasha ${ }^{1}$, M. A. Helmy ${ }^{2}$ and A.W. Zaghlol ${ }^{3}$

\begin{abstract}
Egypt has a high potential of solar energy, which can be considered as a reliable energy source during most of year because it lies within the subtropical regain. Sun tracking and reflector System was designed in Agricultural Engineering Dept., Faculty of Agric., Kafrelsheikh University and performed in summer and winter 2010/2011 at Rice Mechanization Center (RMC), Meet El-Deyba, Kafr El-Sheikh Governorate Egypt. Therefore, the main objectives of the present study were: to design sun tracking system of the photovoltaic modules horizontally and vertically with reflector under different operation conditions. The treatments were panel temperature in (summer and winter), daily solar radiation, panel tilt angles: $\left(0^{\circ}-20^{\circ}-30^{\circ}\right.$ in summer $)$ and $\left(0^{\circ}-30^{\circ}-50^{\circ}\right.$ in winter), panel orientation: (toward south along daytime- sun tracking from east to west) and using mirror as reflector of sun rays. The results illustrated that, by increasing panel temperature tended to decrease both of maximum output power PV and panel efficiency at constant of solar radiation. By increasing solar radiation from 200 to $911.39 \mathrm{~W} / \mathrm{m}^{2}$ tended to increase both of maximum output power $P V$ and panel efficiency by 77.18 and $7.91 \%$, respectively at $P V$ temperature of $30^{\circ} \mathrm{C}$. The best performance of panel was achieved when panel was sun tracking from east to west at panel tilt angle of $20^{\circ}$ in summer and $50^{\circ}$ in winter. The values of daily collected radiation, maximum output power and panel efficiency were $683.22 \mathrm{~W} / \mathrm{m}^{2}, 98.18 \mathrm{~W}$ and $9.69 \%$ in summer and $518.85 \mathrm{~W} / \mathrm{m}^{2}, 87.73 \mathrm{~W}$ and $11.669 \%$ in winter, respectively. The gain in collected radiation and output electric power due to sun tracking was higher than the gain in collected radiation and output electric power due to change the tilt angle. The benefit ratio of
\end{abstract}

${ }^{1}$ Asst. Prof. Agric. Eng. Dept., Faculty of Agric, Kafrelsheikh University, Egypt.

${ }^{2}$ Em. Prof. Agric. Eng. Dept., Faculty of Agric, Kafrelsheikh University, Egypt

${ }^{3}$ Asst. Researcher, Agric. Eng. Res. Inst., Agric. Res. Center, Egypt.

Misr J. Ag. Eng., April 2017 
collected radiation is higher than the benefit ratio of output electric power for all operations in summer and winter. The performance of the panel improved by the application of the reflector.

\section{INTRODUCTION}

$\mathrm{P}$ hotovoltaic (PV) panel is one of the most important renewable energy technologies for converting sunlight into electric energy. solar energy has focused on the methods to efficiency enhancement and maximization of performance. Helwa et al. (2000) showed that solar tracked PV array system, single-axis or two- axis solar tracking mechanisms are used where PV panel is mounted on the device to track the sun. Rönnelid et al. (2000) found that stationary, flat reflectors mounted at the front of nonofficial PV modules had increased the annual output of the module by an order of 20-25\%. Cell temperature and irradiance distribution on a PV panel are of vital importance to the performance of the panel. The increase in cell temperature with increased irradiance is one major difficulty associated with application of reflective materials to PV panel systems in Sweden. Ahmed and Hussein (2001) showed that the application of the reflector on the photovoltaic panel increased the incident solar radiation on the photovoltaic panel. Harrison (2001) showed that the performance of the panel degrades with the increase in temperature as the efficiency of the panel decreased with the increase in temperature. Vilela et al. (2003) mentioned that the irradiation collected by the tracker plane is 19 and $24 \%$ higher than the one collected by the fixed system. Faiman et al. (2003) showed that Traditional ways of achieving high intensity of solar radiation on PV panel are solar tracked PV array system and concentrating systems. Karimov et al. (2004) stated that another way of increasing intensity of solar radiation on PV panel is by focusing the solar radiation on it. Hussein et al. (2004) showed that With the PV panel oriented at latitude angle so as to optimize the intensity of solar radiation, the solar tracking reflective mirror will increase the incident solar radiation. The increased solar radiation will thus improve the total output of the PV panel. ElSayed et al. (2005) noticed that the module efficiency was negatively affected by the ambient air temperature. Ghoneim (2006) said that the 
maximum power point tracker is adopted to force the PV array to work at maximum power, thus improving the system efficiency. Tonapi and Larochelle (2006) discussed that tracking mechanism will continuously reflect the solar radiation on the stationary photovoltaic panel throughout the day. Kulkarni et al. (2007) used Mirror Positioning Device (MPD) to achieve optimum reflection throughout the day a novel solar tracking mechanism augmented with a reflector mirror because the position of the sun changes throughout the day. Also, they found that maximal current ( $\mathrm{I}_{\max }$ value does not vary much with the variation of the temperature. There is a slight reduction in maximal voltage $\left(\mathrm{V}_{\max }\right)$ value as the temperature of the panel increases. Consequently there is slight decrease in the efficiency with the increase in temperature. Meah et al. (2008) said that the fixed system gets less sunlight but ends up being more reliable and needing less maintenance. Also, they showed that as the sun changes its angular position over the year, the solar array angle needs to be adjusted according to the sun's angle. Dong (2009) discussed that as panel tilt decreased, the percent insolation of the front panel increased. The optimum tilt angle for the front PV panel was not in agreement with theory under cloudy weather conditions. However, he said that there was currently no information on which type of reflector surface profile will yield the best PV module performance. Li et al. (2011) showed that solar irradiation intensity had certain effects on the solar cell's performance. Rekioua et al. (2013) said that to maximize the efficiency of the system, it is necessary to track the maximum power point of the PV array. Bentaher et al. (2014) said that the deflection of sun rays on a solar photovoltaic panel can reduce its power output until $50 \%$. They constructed and tested a simple tracking system based on light dependent resistors. This system was used for the command of photovoltaic panels. Belhadj et al. (2016) studied the photovoltaic system concentration, by two plates reflective to increase the intensity of solar radiation on the panel plates. Naik and Gaonkar (2016) presented a simple single axis automatic sun tracking system for the solar panel. This tracking system uses the voltage delivered to the load as a sensing parameter to orient the solar panel for normal incidence of sunrays. Therefore, the main objective of this work was design and built of the sun tracking device of the photovoltaic cells horizontally and vertically 
with the direction of the sun and reflector to be suitable for the requirements of accuracy direction and increasing the solar radiation received by the modules under different operation conditions.

\section{MATERIAL AND METHODS}

Sun tracking and reflector were designed in Agricultural Engineering Dept., Faculty of Agric., Kafrelsheikh University. The experiments were tested and performed in summer and winter 2010/2011 at Rice Mechanization Center (RMC), Meet El-Deyba, Kafr El-Sheikh Governorate, Egypt which is located at $31^{\circ} 6^{\prime} \mathrm{N}$ latitude, $30^{\circ} 50^{\prime} \mathrm{E}$ longitude, and an elevation of about 6 meters above mean sea level during a different clear sunny days to achieve the optimum PV panel tilt angle, orientation of sun tracking and sun array reflection at which the highest power output and efficiency.

\subsection{System Description}

The main parts of proposed system were sun tracking device and reflector.

\subsubsection{Sun tracking device}

Sun tracking device was manufactured to use in this study as shown in sketch of Figure 1.a and photograph of Figure 1.b. It adjusted the direction of the photovoltaic cell horizontally and vertically with the direction of the sun. It consists of nine components: photovoltaic cells, device of horizontal control, device of vertical control, index of the sun perpendicular on photovoltaic cells, battery holder and measuring device, frame, axial wheel with brake, thermoelectric Pyranometer to measure insolation and handles to fixing the inclination and direction of photovoltaic cells.

\subsection{1.a The horizontal control device :}

The horizontal control device consists of a frame $(190 \mathrm{~cm}$ length and $104 \mathrm{~cm}$ width and $3 \mathrm{~cm}$ thickness made from pipe metal square section $(3 \times 3 \mathrm{~cm})$ type. It mounted on two ball bearings fixed on steel frame. The dimensions of the frame are $116 \mathrm{~cm}$ long, $54 \mathrm{~cm}$. width and $3 \mathrm{~cm}$ thickness. Fixed on cylinder, $(112 \mathrm{~cm}$ length and $6 \mathrm{~cm}$ diameter) rotate by 


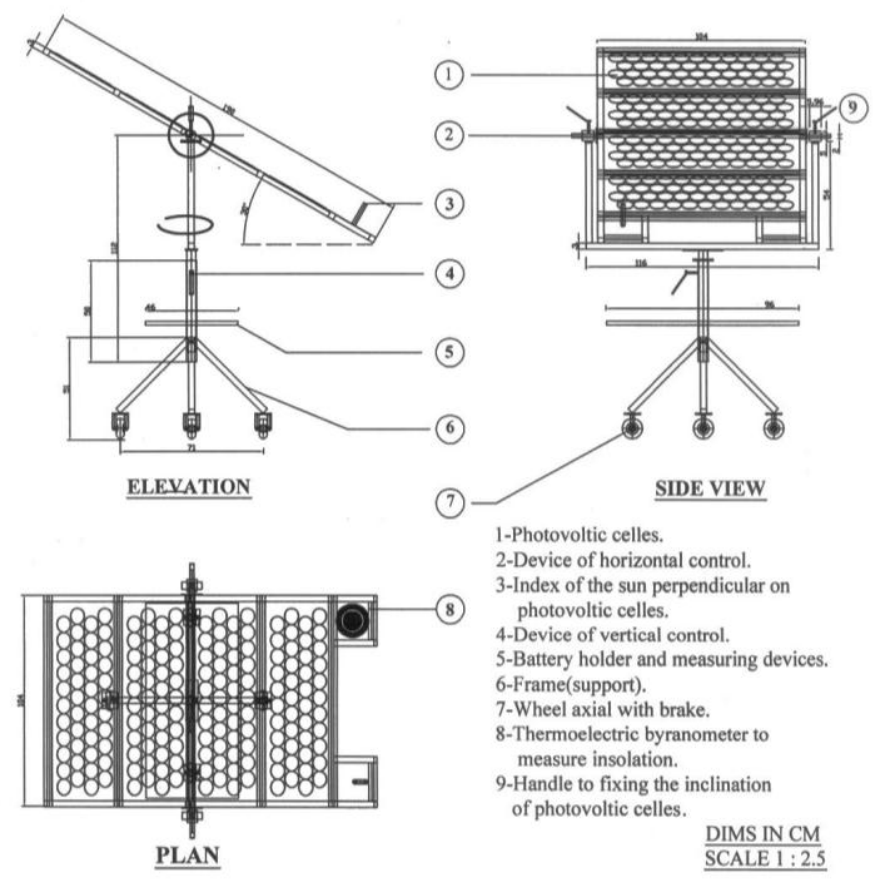

Figure 1.a. Sketch of sun tracking device with the photovoltaic modules

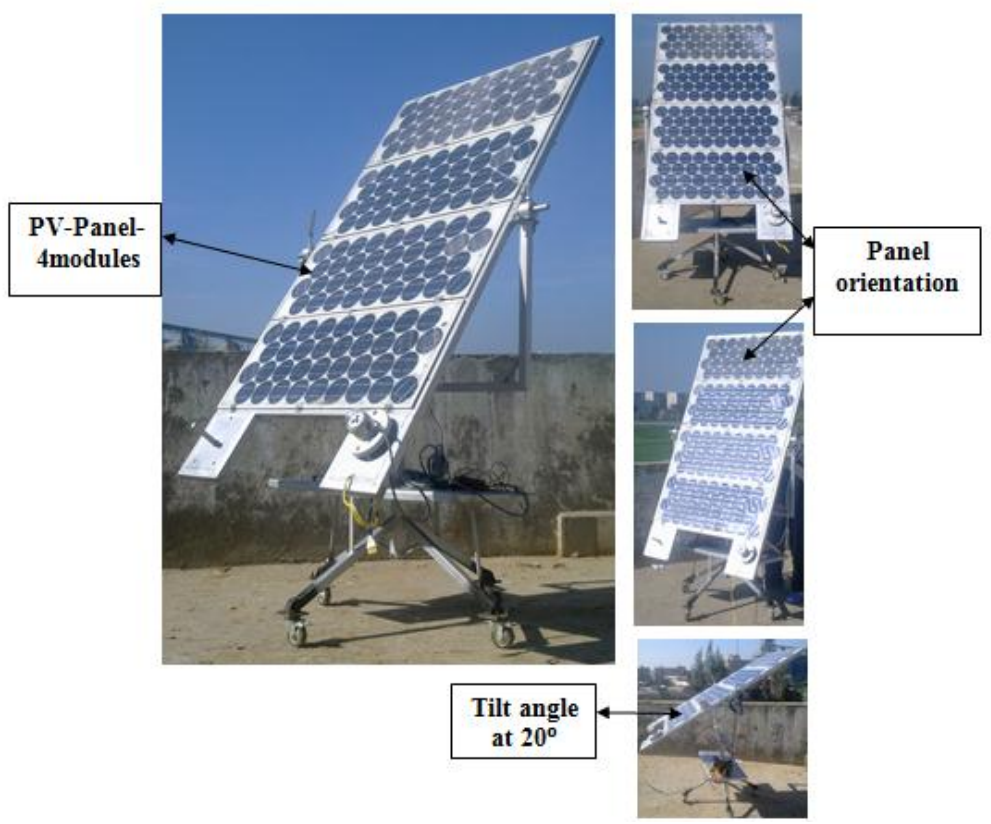

Figure 1.b. Photograph of sun tracking device with the photovoltaic modules 
$320^{\circ}$ around the horizontal axial and there is handle supported on each ball bearing to fixing the inclination of photovoltaic cells.

\subsection{1.b The vertical control device}

The vertical control device consists of a cylinder, $(112 \mathrm{~cm}$ length and $4.5 \mathrm{~cm}$ diameter) rotate inside cylinder $(50 \mathrm{~cm}$ length and $6 \mathrm{~cm}$ diameter) rotate $360^{\circ}$ around the vertical axial and there is handling supported on the outer cylinder to fixing the direction of photovoltaic cells.

\subsection{1.c The frame of device}

The frame was constructed from pipe metal square section, $(3 \times 3 \mathrm{~cm})$ welded together to form the device. The device has four axial wheels with brake.

\subsubsection{The reflector}

It is a flat mirror with dimensions of $104 \times 44 \mathrm{~cm}$ to reflect solar radiation on the PV module as shown in Figure 2.

\subsubsection{Solar modules}

The PV array (ExSolar 300 Series) has a capacity of 140 peak Watt (four modules, 35 peak Watt each and $586 \times 410 \times 25 \mathrm{~mm}$ size), $21.8 \mathrm{~V}$ open circuit voltage $\left(\mathrm{V}_{\mathrm{OC}}\right), 2.27 \mathrm{~A}$ short circuit current $\left(\mathrm{I}_{\mathrm{SC}}\right)$, and mounted on sun tracking device surface.

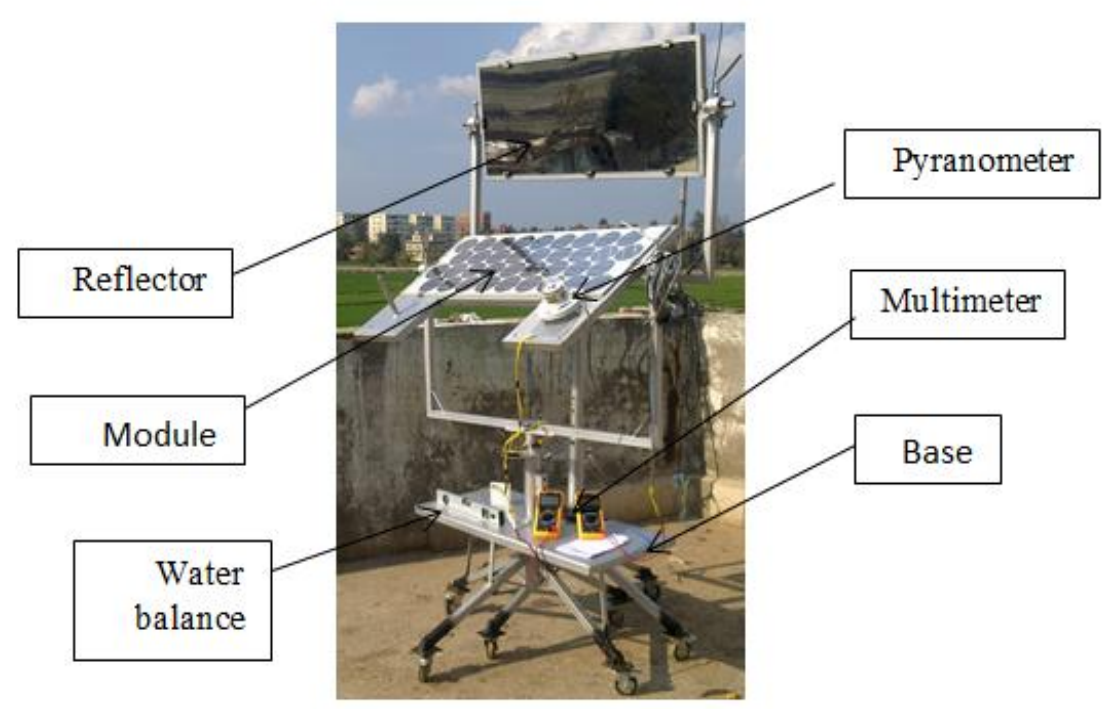

Figure 2. Photograph of reflector with module 


\subsection{Experimental treatments}

\subsubsection{Orienting the PV array}

The PV array has got a tracking arrangement for orienting the panel towards east (from 9.00 to $13.00 \mathrm{~h}$ ), south (from 13.00 to $16.00 \mathrm{~h}$ ) and west ( from 16.00 to $19.00 \mathrm{~h}$ ) directions in summer season. The PV array has got a tracking arrangement for orienting the panel towards east (from 9.00 to $12.00 \mathrm{~h}$ ), south (from 12.00 to $15.00 \mathrm{~h}$ ) and west ( from 15.00 to $17.00 \mathrm{~h}$ ) directions in winter season.

\subsubsection{Tilt angle and the sun tracking test}

The experimental setup for the tilt angle and sun tracking test was:

Panel tilted at $0^{\circ}$; panel tilted at $20^{\circ}$ without tracking the sun; panel tilted at $20^{\circ}$ with tracking the sun from east to west; panel tilted at $30^{\circ}$ without tracking the sun and panel tilted at $30^{\circ}$ with tracking the sun from east to west. These angles as illustrated in Figure 3. The PV panels were tested at tilt angles $0^{\circ}, 20^{\circ}$ and $30^{\circ}$ in summer and $0^{\circ}, 30^{\circ}$, and $50^{\circ}$ in winter. At winter the applied angles were $0^{\circ}, 30^{\circ}$ and $50^{\circ}$ with and without sun tracking in each angle. The improvement due to changing tilt angle is assessed by comparing the improvement in the output of the PV panel in terms of efficiency.

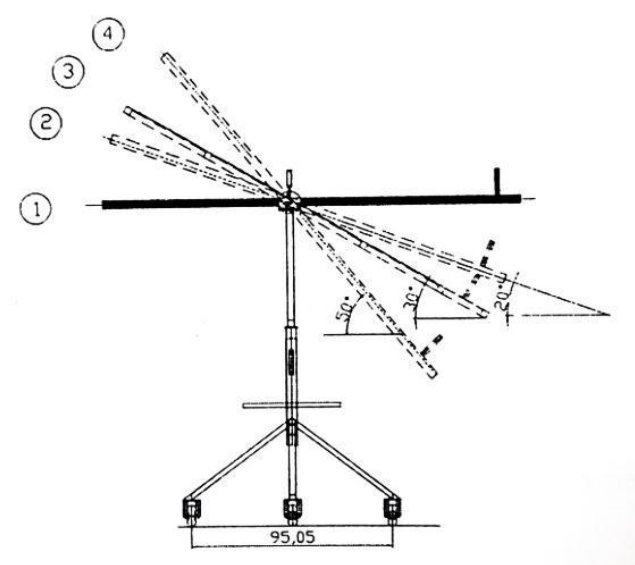

Figure 3. Setup for tilt angle test.

\section{2-2-3 Reflector}

The purpose of the reflector experiment was to determine the optimum tilt angle of the PV panel matching with reflector at which the highest power output could be achieved. This experiment employed a reflector 
surface like mirror to reflect the rays on to PV module. The performance was compared with the same PV module without reflector under the same environmental conditions in winter 2011. The improvement due to application of the reflector is assessed by comparing the improvement in the output of the photovoltaic panel in terms of efficiency. The PV module tracked with sun from east to west at tilt angle $30^{\circ}$. The reflector was moving with the PV module at tilt angle $7^{\circ}$ which was determined by experiment.

\subsection{Measuring Instruments}

The experimental test stand was comprised of: Pyranometer, two multimeter, compass, anglevel meter, water balance, digital thermometer, metal meter, and stop watch.

\subsection{Methods}

\subsubsection{Determination of input and output power}

The insolation to the PV array gives the input power to the system and output power by using equations as follows (Hamza and Taha 1995):

$$
\begin{aligned}
& P_{\text {in }}=I_{n s} \times A . . \\
& P_{\text {out }}=V_{o c} \times I_{s c}
\end{aligned}
$$

Where: $\mathrm{P}_{\text {in }}$ : input power $(\mathrm{W})$; $\mathrm{P}_{\text {out }}$ : output power $(\mathrm{W})$; $\mathrm{I}_{\mathrm{ns}}$ : insolation $\left(\mathrm{W} / \mathrm{m}^{2}\right)$; A: solar module area $\left(\mathrm{m}^{2}\right) ; \mathrm{V}_{\mathrm{oc}}$ : open circuit voltage $(\mathrm{V}) ; \mathrm{I}_{\mathrm{sc}}$ : short circuit current (A)

\subsubsection{PV panel efficiency}

PV panel efficiency $\left(\eta_{\text {panel }}\right)$ is the ratio between output power to input power. It was calculated by the following equation (Hamza and Taha 1995):

$$
\eta_{\text {panel }}=\frac{P_{\text {out }}}{P_{\text {in }}} \times F F=\frac{V_{O C} \times I_{S C} \times F F}{I_{n s} \times A} \times 100 .
$$

Where: FF: fill factor which equals about 0.67 for $\mathrm{Si}$. 


\subsubsection{Benefit ratio}

Benefit ratio of solar radiation, $\quad B R R=\frac{R(\text { with } \text { reflector })}{\mathrm{R}(\text { without reflector })} \ldots \ldots . . .(4)$

Where: R: solar radiation, $\mathrm{W} / \mathrm{m}^{2}$

Benefit ratio of output electric power, $B R P=\frac{P(\text { with reflector })}{\mathrm{P}(\text { without reflector })}$.

Where: P: output power, W

\section{RESULTS AND DISCUSSION}

\subsection{Effect of incident solar radiation and temperature on short circuit current, open circuit voltage, output power and panel efficiency}

The performance parameters of the panel for different incident solar radiation and panel temperature as shown in Table 1 and Figure 4. The results indicated that short circuit current $\left(\mathrm{I}_{\mathrm{SC}}\right)$ and open circuit voltage $\left(\mathrm{V}_{\mathrm{OC}}\right)$ values were increased by increasing in the amount of incident solar radiation, increasing the total output. $\mathrm{I}_{\mathrm{SC}}$ increased considerably by increasing in the incident solar radiation. Value of $\mathrm{I}_{\mathrm{SC}}$ for $911.39 \mathrm{~W} / \mathrm{m}^{2}$ was about of 4.19 times the $\mathrm{I}_{\mathrm{SC}}$ for $200 \mathrm{~W} / \mathrm{m}^{2}$. But the value of $\mathrm{V}_{\mathrm{OC}}$ was comparatively very small as the $\mathrm{V}_{\mathrm{OC}}$ for $911.39 \mathrm{~W} / \mathrm{m}^{2}$ was only about of 1.04 times the $\mathrm{V}_{\mathrm{OC}}$ for $200 \mathrm{~W} / \mathrm{m}^{2}$. Also, increasing panel temperature tended to decrease both of output power and panel efficiency. The short circuit current $\left(\mathrm{I}_{\mathrm{SC}}\right)$ and the open circuit voltage $\left(\mathrm{V}_{\mathrm{oc}}\right)$ values were decreased by increasing of the panel temperature. The values of short circuit current and open circuit voltage were decreased by about of $0.58 \mathrm{~A}$ and $0.97 \mathrm{~V}$ when panel temperature increased from $27^{\circ} \mathrm{C}$ to $47^{\circ} \mathrm{C}$, respectively. This led to reduce the generated electric power by the solar module. That emphasis the necessity of reducing the module surface temperature especially, in the hot climatic conditions in Egypt to obtain asatisfactory electric power using the solar modules techniques. On the other hand, the module efficiency was negatively affected by the panel temperature. Flat relationship between the module surface temperature and the module efficiency as observed. For a panel temperature increased by one celsius, aslight reduction in the solar module efficiency of $0.06 \%$ 
was obtained. The reduction in the efficiency of the solar module was specified for the silicon type that the solar module was manufactured and fabricated.

Table 1: The short circuit current and the open circuit voltage performance of the panel at different solar radiation for constant panel temperature of $30^{\circ} \mathrm{C}$.

\begin{tabular}{|c|c|c|}
\hline Radiation, $\left(\mathrm{W} / \mathrm{m}^{2}\right.$ & $\mathrm{I}_{\mathrm{SC}},(\mathrm{A})$ & $\mathrm{V}_{\mathrm{OC}},(\mathrm{V})$ \\
\hline 200 & 1.53 & 19.1 \\
\hline 314.29 & 2.4 & 19.5 \\
\hline 571.43 & 4.35 & 19.7 \\
\hline 730.85 & 5.22 & 19.9 \\
\hline 911.39 & 6.42 & 19.95 \\
\hline
\end{tabular}

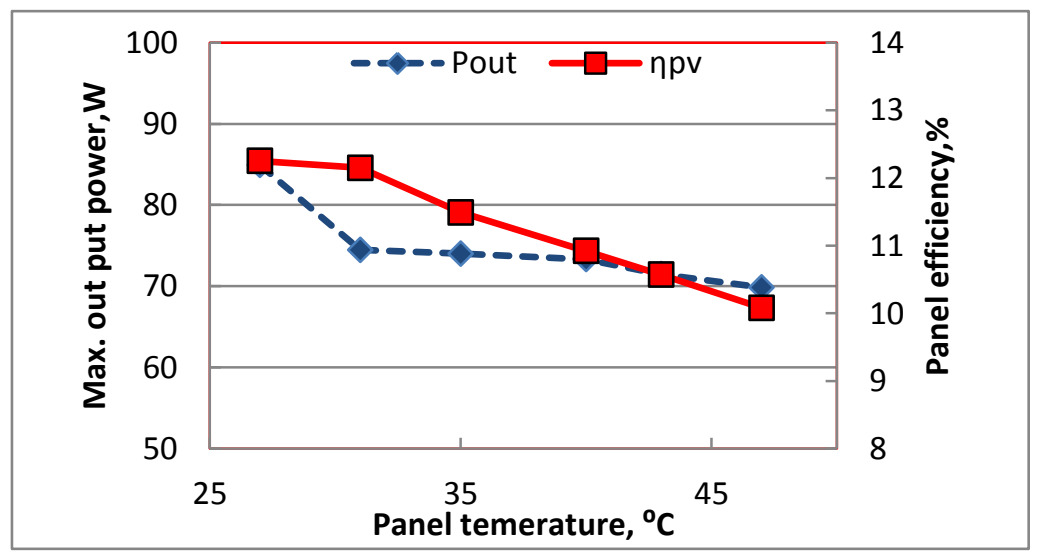

Figure 4. Effect of different panel temperatures on output electric power and efficiency of the panel at constant solar radiation of $557.14 \mathrm{~W} / \mathrm{m}^{2}$

\subsection{Effect of tilt angle and tracking system on the collected solar radiation and output electric power of the photovoltaic panel}

Figure 5, 6, 7 and 8 show that solar radiation increase along daytime from sunrise and reach to its maximum value at noon then it decrease 
with sunset in both summer and winter. The output electric power ( $\left.\mathrm{P}_{\text {output }}\right)$ had the same trend of solar radiation. Figure 5 shows the effect of tilt angle at fixed panel oriention (south along the day) in summer. Average solar radiation $(\mathrm{R})$ and output electric power $\left(\mathrm{P}_{\text {output }}\right)$ values on horizontal plane (tilt angle of the panel was zero ${ }^{\circ}$ ) were $514.81 \mathrm{~W} / \mathrm{m}^{2}$ and $74.88 \mathrm{~W}$, respectively. At tilt angle equal to latitude angle $\left(30^{\circ}\right)$, the values of average solar radiation $(\mathrm{R})$ and output electric power $\left(\mathrm{P}_{\text {output }}\right)$ were $559.23 \mathrm{~W} / \mathrm{m}^{2}$ and $81.03 \mathrm{~W}$, respectively. At tilt angle $20^{\circ}$ (latitude angle- $10^{\circ}$ ), the average solar radiation $(\mathrm{R})$ and output electric power $\left(\mathrm{P}_{\text {output }}\right)$ values were increasesd to $603.66 \mathrm{~W} / \mathrm{m}^{2}$ and $87.18 \mathrm{~W}$, respectively because the amount of perpendicularly incident radiation on the panel increased with changing tilt angle from $0^{\circ}$ to $30^{\circ}$ to $20^{\circ}$. Consequently, the output electric power increased with changing tilt angle. Figure 6 shows the effect of sun tracking from east to west along daytime in summer. At constant tilt angle equal $30^{\circ}$ the average solar radiation $(\mathrm{R})$ and output electric power $\left(\mathrm{P}_{\text {output }}\right)$ values for tracking system were $645.47 \mathrm{~W} / \mathrm{m}^{2}$ and $92.80 \mathrm{~W}$, respectively but these values were $559.27 \mathrm{~W} / \mathrm{m}^{2}, 81.03 \mathrm{~W}$ with fixed system, respectively. Figure 7 shows the effect of tilt angle at fixed panel oriention (south along the day )in winter. The general trend of solar radiation and output power along daytime as the same as in summer but the difference was in the values. Average solar radiation $(\mathrm{R})$ and output electric power $\left(\mathrm{P}_{\text {output }}\right)$ values on horizontal plane (tilt angle of the panel was zero ${ }^{\circ}$ ) were $345.24 \mathrm{~W} / \mathrm{m}^{2}$ and $59.51 \mathrm{~W}$, respectively. At tilt angle equal to latitude angle $\left(30^{\circ}\right)$, the values of average solar radiation $(\mathrm{R})$ and output electric power $\left(\mathrm{P}_{\text {output }}\right)$ were $442.460 \mathrm{~W} / \mathrm{m}^{2}$ and $75.140 \mathrm{~W}$, respectively. At tilt angle $50^{\circ}$, the average solar radiation $(\mathrm{R})$ and output electric power $\left(\mathrm{P}_{\text {output }}\right)$ increased to $470.24 \mathrm{~W} / \mathrm{m}^{2}$ and $78.804 \mathrm{~W}$, respectively. Figure 8 shows the effect of tracking the sun from east to west along daytime in winter. the general trend of solar radiation and output power along daytime due to sun tracking is the same as in summer but the difference was in values. At constant tilt angle equal $30^{\circ}$ the average solar radiation $(\mathrm{R})$ and output electric power $\left(\mathrm{P}_{\text {output }}\right)$ values for tracking system were $473.21 \mathrm{~W} / \mathrm{m}^{2}$, $79.878 \mathrm{~W}$, respectively but there values were $442.460 \mathrm{~W} / \mathrm{m}^{2}, 75.140 \mathrm{~W}$ with fixed system, respectively. Therefore, the suitable tilt angle in summer and winter is $20^{\circ}$ and $50^{\circ}$, respectively. 




Figure 5. Effect of daytime on solar radiation and output electric power at different tilt angles $\left(0^{\circ}, 20^{\circ}\right.$ and $\left.30^{\circ}\right)$ and fixed system toward south and sun tracking from east to west throughout the courses of days in summer, 2010.

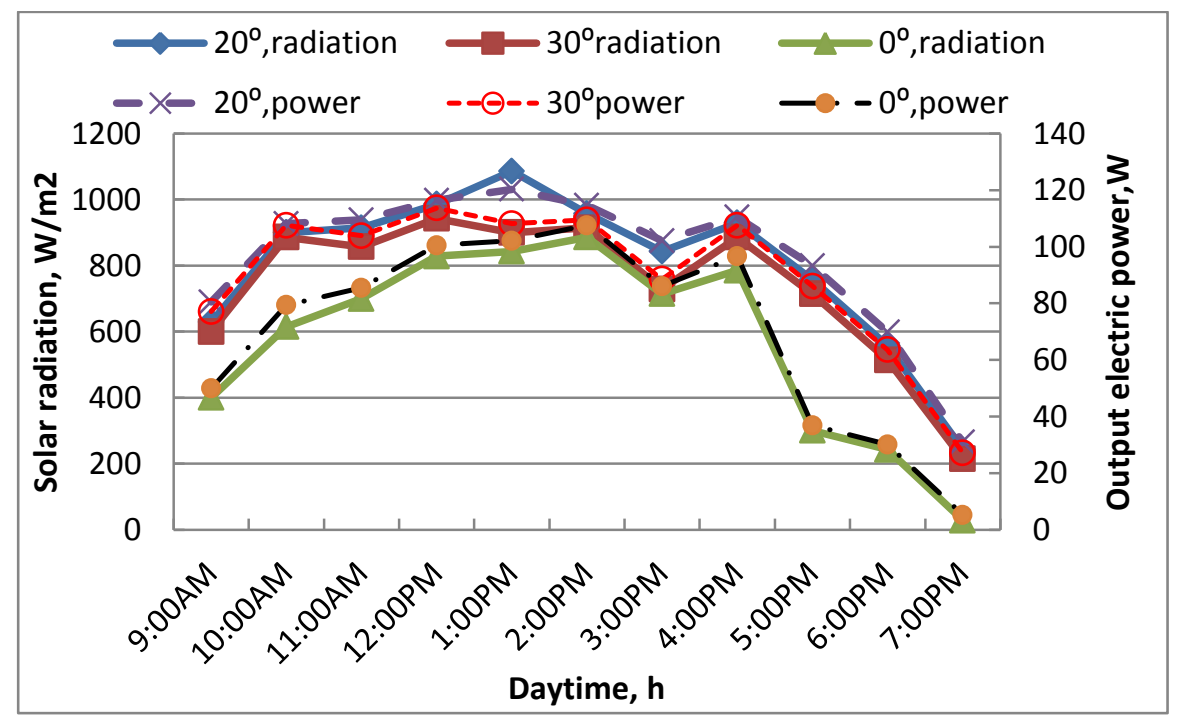

Figure 6. Effect of daytime on solar radiation and output electric power at different tilt angles $\left(0^{\circ}, 20^{\circ}\right.$ and $\left.30^{\circ}\right)$ and moved system by sun tracking device from east to west throughout the courses of days in summer, 2010 


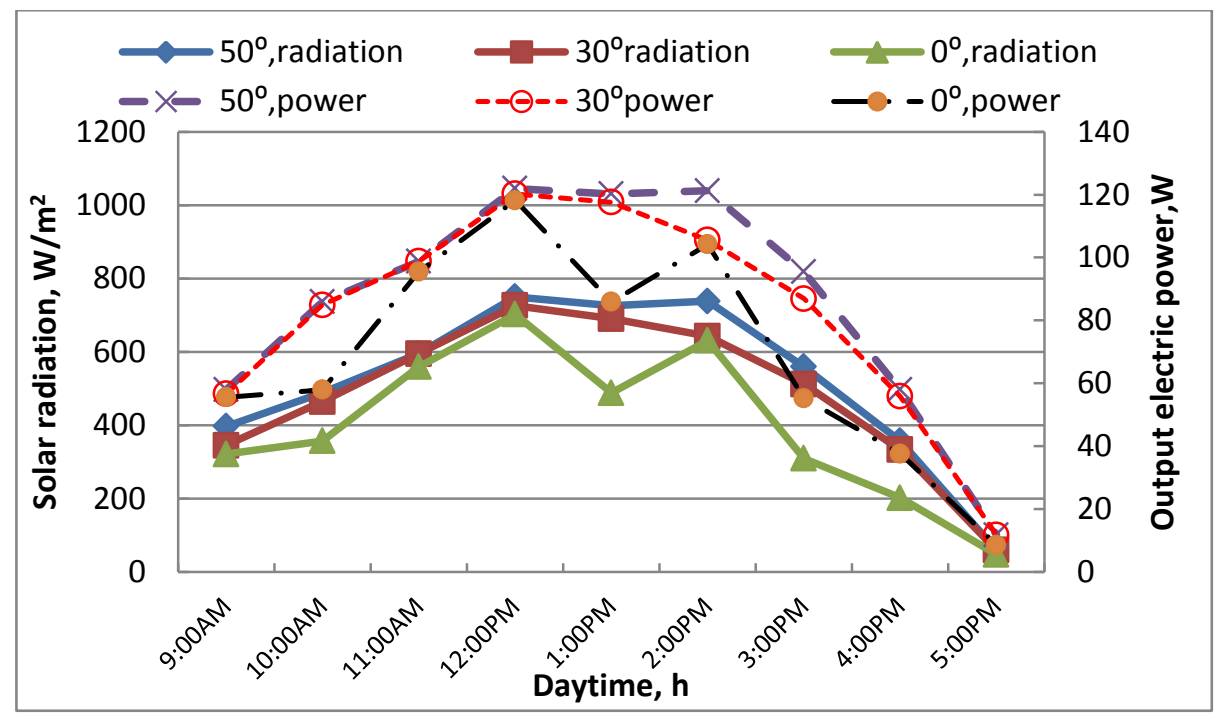

Figure 7. Effect of daytime on solar radiation and output electric power at different tilt angles $\left(0^{\circ}, 30^{\circ}\right.$ and $\left.50^{\circ}\right)$ and fixed system toward south and sun tracking from east to west throughout the courses of days in winter, 2011.

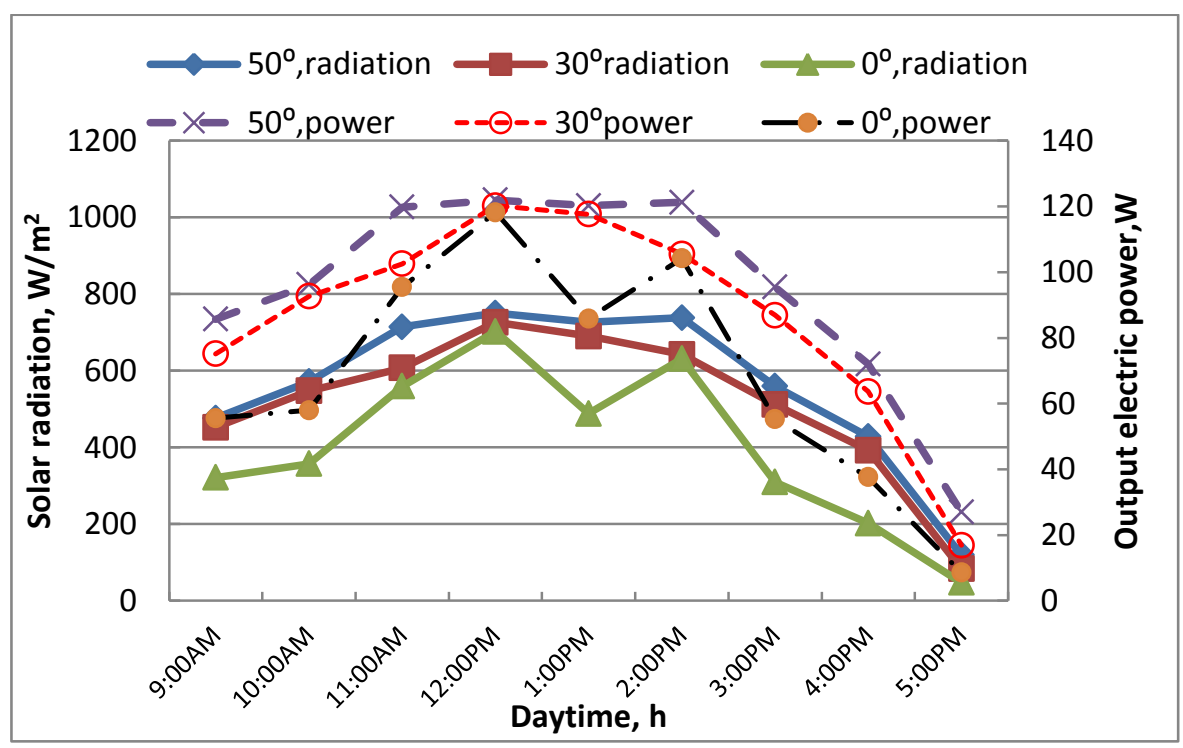

Figure 8. Effect of daytime on solar radiation and output electric power at different tilt angles $\left(0^{\circ}, 30^{\circ}\right.$ and $\left.50^{\circ}\right)$ and moved system by sun tracking device from east to west throughout the courses of days in winter, 2011.

Tracking system achieved higher amount of collected solar radiation and output electric power than the fixed system in summer and winter. The gain of collected solar radiation and output electric power due to change the tilt angle as compared with the gain due to tracking sun system can be 
obtained by using benefit ratio (BR). Which affected highly, changing of tilt angle or tracking sun? And which increased highly, the gain of collected radiation or the gain of output electric power? Figures 9 and 10 show the effect of interaction between tilt angle and sun tracking on the benefit ratio of collected solar radiation (BRR) and output electric power (BRP). There are three different operations as follows: panel tilted at $20^{\circ}$ in summer and $50^{\circ}$ in winter with the panel sun tracking from east to west along daytime (operation1), panel tilted at $30^{\circ}$ with the panel sun tracking from east to west along daytime (operation2) and panel tilted at $20^{\circ}$ in summer and $50^{\circ}$ in winter with panel oriented toward south along daytime (operation3). The previous operations were compared with panel tilted at $30^{\circ}$ (latitude angle) and panel was oriented toward south along daytime.

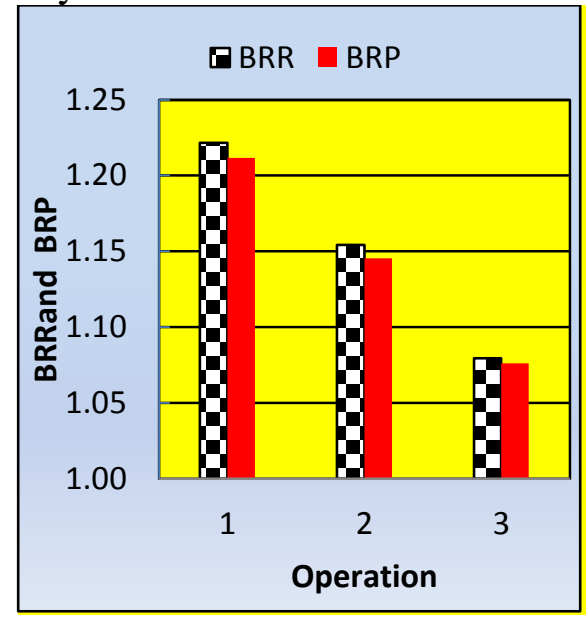

Figure 9. Effect of orientation and tilt angle on the benefit ratio of collected radiation and output electric power in summer 2010

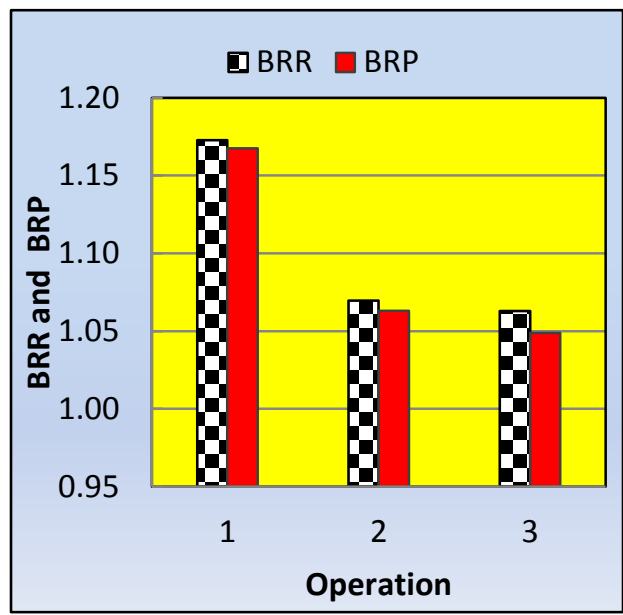

Figure 10. Effect of orientation and tilt angle on the benefit ratio of collected radiation and output electric power in winter 2011

The benefit ratio of collected radiation (BRR) and output electric power (BRP) were 1.222 and 1.212 in summer, respectively but these values were 1.173 and 1.168 in winter, respectively at operation 1 . The benefit ratio of collected radiation (BRR) and output electric power were 1.154 and 1.145 in summer, respectively but these values 1.070 and 1.063 in winter, respectively at operation 2 . The benefit ratio of collected radiation (BRR) and output electric power (BRP) were 1.079 and 1.076 in summer, respectively but these values were 1.063 and 1.049 in winter 
respectively at operation 3 . Therefore, the maximum ratios were achieved by operation 1 at summer and winter. Also, the benefit ratio of collected radiation (BRR) is higher than the benefit ratio of output electric power (BRP) for all operations in summer and winter.

\subsection{Effect of solar radiation and stationary reflector on the panel efficiency}

The effect of solar radiation and reflector on the panel efficiency as divided into five groups according to different values of solar radiation (R) as shown in Figure 11. The reflector was tilted at $7^{0}$ and sun tracking system from east to west in winter. When the values of radiation were $\{R$ $\leq 135.71\}$, there is no effect on efficiency.

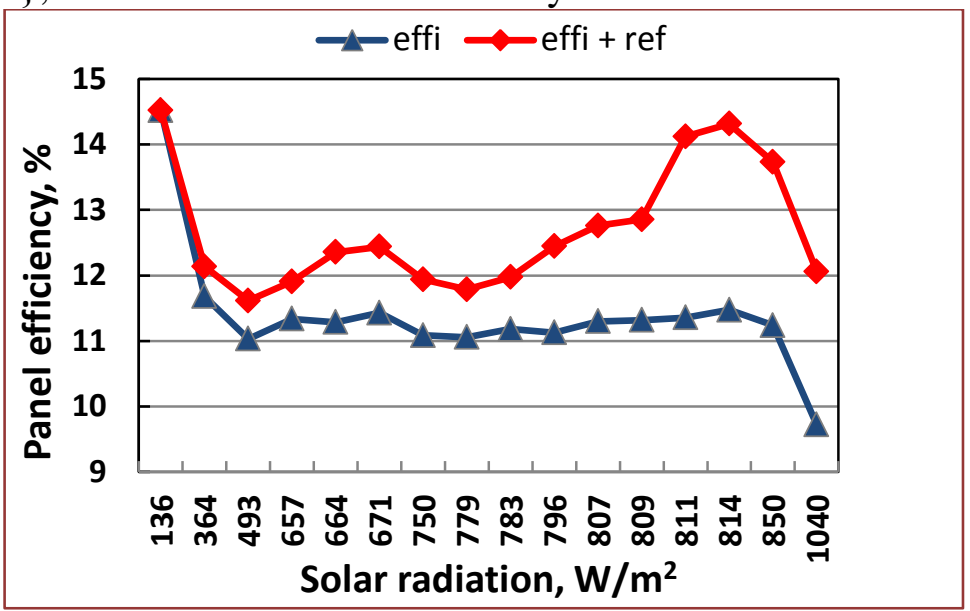

Figure 11: The effect of solar radiation and reflector on panel efficiency

When the values of radiation were $\{364.28 \leq \mathrm{R} \leq 657.14\}$, the average improvement efficiency was $4.735 \%$. When the values of radiation were $\{664.29 \leq \mathrm{R} \leq 782.86\}$, the average efficiency increased by $7.936 \%$. When the value of radiation were $\{795.71 \leq \mathrm{R} \leq 808.57\}$, the average improvement efficiency reached to $12.78 \%$. Increasing the values of radiation were $\{811.43 \leq \mathrm{R} \leq 1040\}$ lead to maximize the efficiency by $23.84 \%$. The panel efficiency improved by application of the reflector. Thus, the positive effect of solar radiation increasing on the panel efficiency was more than the negative effect due to increase in panel temperature.

\section{CONCLUSIONS}

It has been concluded that:

- The PV efficiency was negatively affected by the panel temperature. 
- The suitable tilt angle in summer and winter is $20^{\circ}$ and $50^{\circ}$, respectively.

- Appllication of sun tracking system with changing tilt angle of the panel to $20^{\circ}$ in summer and $50^{\circ}$ in winter, the benefit ratio of collected radiation (BRR) and output electric power (BRP) increase to 1.222 and 1.212 in summer and 1.173 and 1.168 in winter, respectively.

- Application of reflector, the output power and panel efficiency increase for the same panel area.

- Sun tracking system achieved higher amount of collected solar radiation and output electric power than the fixed system in summer and winter.

- The optimum tilt angles for using reflector with panel were $30^{\circ}$ for PV panel and $7^{\circ}$ for reflector.

\section{REFERANCES}

Ahmed, G. E. and H. M. S. Hussein (2001). Comparative study of PV module with and without a tilted plane reflector. Energy conversion and management. 42: 1327-1333.

Belhadj, M.; T. Benouaz and S. Bekkouche (2016). Modeling of Automatic Reflectors for PV panel Attached to Commercial PV/T Module. International Journal of Applied Engineering Research. 11(23): 11309-11314.

Bentaher, H.; H. Kaich; N. Ayadi; M. B. Hmouda; A. Maalej and U. Lemmer (2014). A simple tracking system to monitor solar PV panels. Energy conversion and management.78: 872-875.

Dong, R. (2009). Optimizing Reflection and Orientation for Bifacial Photovoltaic Modules. Thesis, department mechanical engineering, Ohio State University.

El-Sayed, A. S.; S. M. Radwan; A. A. Hassanain and S. M. Mosalhi (2005). Weather effects on performance of solar module for water pumping. Misr Journal of agricultural engineering. 22(3): 874-898.

Faiman, D.; D. Berman; D. Bukobza; S. Kabalo; I. Karki; B. Medwed; V. Melnichak; E. Held and H. Oldenkamp (2003). A 1-year, side-by-side comparision of: static; 1-axis tracking; and Vthrough mirror assisted grid connected PV modules in a desert environment. $3^{\text {rd }}$ World Conference on Photovoltaic Energy Conversion, pp. 2190-2193.

Ghoneim, A. A. (2006). Design optimization of photovoltaic powered 
water pumping systems. Energy Conversion and Management 47:1449-1463.

Hamza, A. A. and A. Z. Taha (1995). Performance of submersible PV solar pumping systems under conditions in the Sudan. Renewable energy. 6(5): 491-495.

Harrison, J. (2001). Investigation of Reflective Materials for the Solar Cooker," Solar Energy Web Site, Florida Solar Energy Center.

Helwa, N. H.; A. B. G. Bahgat; A. M. R. El-Shafee and E. T. ElShenawy (2000). Computation of the Solar Energy Captured by Different Solar Tracking Systems. Energy Sources, Part A: Recovery, Utilization, and Environmental Effects. 22: 35 - 44.

Hussein, H. M. S.; G. E. Ahmed and H. H. El-Ghetany (2004). Performance evaluation of photovoltaic modules at different tilt angles and orientations. Energy conversion and management. 45: 2441-2452.

Karimov, K. S.; M. A. Saqib; P. Akhter; M. M. Ahmed; J. A. Chattha and S. A. Yousadzai (2004). A simple photo-voltaic tracking system. Solar energy materials and solar cells. 87: 49-59.

Kulkarni, S.; S. Tonapi; P. Larochelle and K. Mitra (2007). Effect of tracking flat reflector using novel auxiliary drive mechanism on the performance of stationary photovoltaic module. ASME International Mechanical Engineering Congress and Exposition. November 11.

Li, M.; X. Ji; G. Li; S. Wei; Y. Li and F. Shi (2011). Performance study of solar cell arrays based on a trough concentrating photovoltaic/thermal system. Applied Energy. 88(9):3218-3227.

Meah, K.; S. Fletcher and S. Ula (2008). Solar photovoltaic water pumping for remote locations. Renewable and Sustainable Energy Reviews. 12: 472-487.

Naik, V. and N. Gaonkar (2016). An Automatic Single Axis Solar Tracking System Using Atmega16microcontroller. International Journal of Energy, Environment and Economics. 24(1): 21-27.

Rekioua, D.; A. Y. Achour and T. Rekioua (2013). Tracking power photovoltaic system with sliding mode control strategy. Energy Procedia. 36: 219-230.

Ronnelid, M.; B. Karlson; P. Krohn and J. Wennerberg (2000). Booster Reflectors for PV Modules in Sweden. Progress in Photovoltaics. 8(3): 279-291.

Tonapi, S. S. and P. M. Larochelle (2006). Design of a mirror 
positioning system to enhance the performance of a PV array. Florida Conference on Recent Advances in Robotics, pp.1-6.

Vilela, O. C.; N. Fraidenraich and C. Tiba (2003). Photovoltaic pumping systems driven by tracking collectors. Experiments and simulation. Solar Energy. 74(1):45-52.

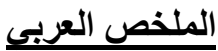

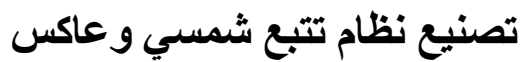 \\ ليناسب الخلايا الكهروضوئية تطت تئية الظروف المصرية}

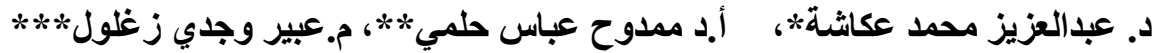

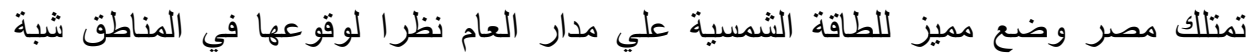
الاستوائية. تم تصميم نظام تتبع او توجيه وعاكس للثمس بقسم الهندسة الزراعية، كلية

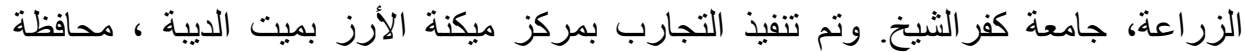

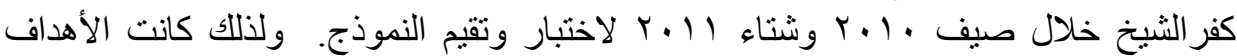

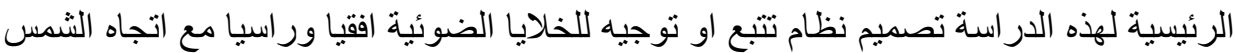

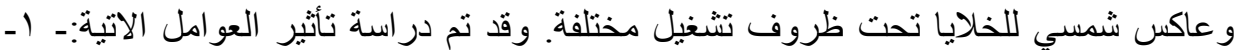

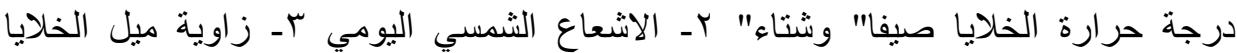

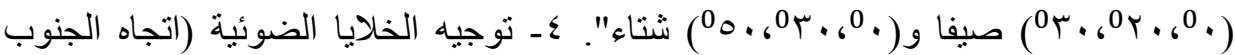

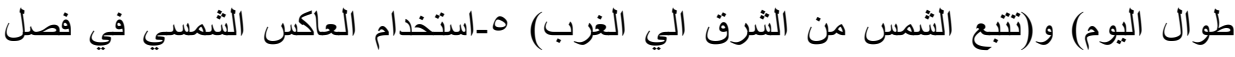

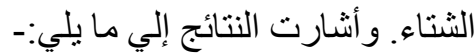

انخفاض كل من القدرة الناتجة من الخلايا الضوئية و الكفاءة بزيادة درجة الحرارة وثبات الاشعاع الشمسي.

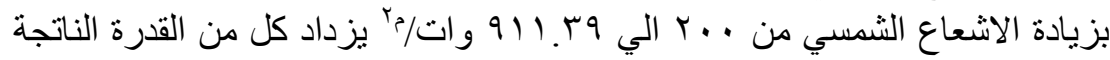

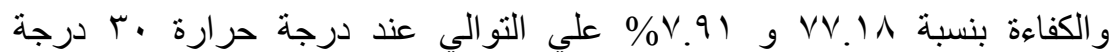
سيليزيوس.

تحقق افضل أداء للخلايا الكهروضوئية عند تتبع الثمس من الثرق للغرب بزاوية

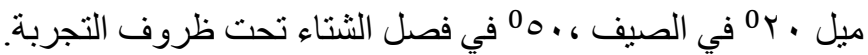
كانت قيم الاشعاع الثمسي اليومي والقدرة الناتجة وكفاءة الخلايا الكهروضوئية

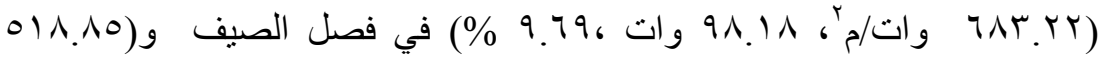

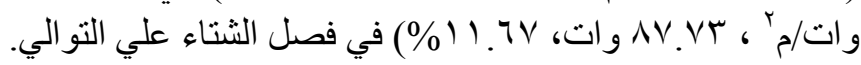
كان معدل الاستفادة من الاشعاع الثمسي و القدرة من الخلايا الكهروضئية الكية نتيجة تنتبع

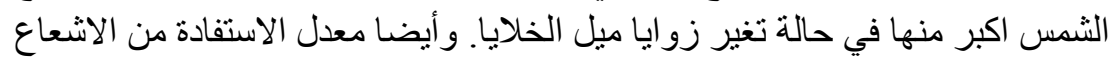
الشمسي اكبر من معدل الاستفادة من القدرة الناتجة من الخلايا الضوئية.

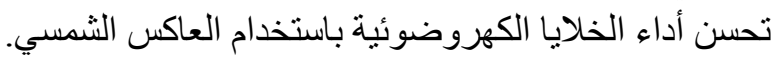

